\title{
Techno-economic assessment of biogas production from press mud in Bangladesh
}

\author{
M. A. Rouf ${ }^{1 *}$, M. S. Islam ${ }^{1}$, P. K. Bajpai ${ }^{2}$ and C. K. Jotshic ${ }^{3}$ \\ ${ }^{1}$ Institute of Fuel Research and Development, Bangladesh Council of Scientific and Industrial Research, \\ Dhanmondi, Dhaka-1205, Bangladesh. \\ ${ }^{2}$ Thapar Centre for Industrial Research \& Development, Patiala, India \\ ${ }^{3}$ Advanched TechnologiesTesting Lab. Inc 4445SW35 terrace, Suite 270 Gainesville, Florida-32608, USA
}

\begin{abstract}
To assess the potential of biogas generation, as a new and renewable source of energy, physico-chemical parameters of press mud have been determined. It has considerable amount of volatile matter (75-80\%) and $\mathrm{C} / \mathrm{N}$ ratio (13-15) is slightly lower than the normal requirement for biomethanation. The total gas yield was $0.18 \mathrm{~L} / \mathrm{g}$ and it contained about $65 \%$ methane. Biogas generation was studied in a $150 \mathrm{cft}$ plant in the field at solid concentrations of 6 to $8 \%$. Acclimatization of the reactor has been done by initial start-up by cow dung and gradual mixing with press mud in order to generate biogas from press mud alone. The profitability of the considered plant has been assessed using the discounting and dynamic Net Present Value methods. The biogas and biofertilizer production from press mud was found to be economically feasible.
\end{abstract}

Keywords: Press mud; Biomethanation; Acclimatization; Profitability

\section{Introduction}

The press mud (also called filter cake) is a solid waste, generated on clarification of cane juice before its concentration and sugar crystallization. For every 100 tons of sugarcane crushed, about 3 tons of press mud cake is left behind as byproduct (Neha et. al. 2011). A schematic diagram of formation of press mud waste from sugar industry is shown in Fig. 1. It is a soft, spongy, light weight, amorphous, dark brown to black colored material. It generally contains 60 $85 \%$ moisture $(\mathrm{w} / \mathrm{w})$; the chemical composition depends on cane variety, soil condition, nutrients applied in the field, process of clarification adopted and other environmental factors. During the clarification of cane juice using sulphitation process, most of the non-sugar components are precipitated by addition of milk of lime and sulphur dioxide. The precipitate is allowed to settle in a clarifier and the settled sludge is filtered by using rotary vacuum filter. The amount of sulphitation process mud cake is about $3-4 \%$ of the weight of the cane crushed (Rao, 1997). It is generally used as a fertilizer.

Due to sugar and other organic constituents, the press mud emits obnoxious odor causing environmental pollution. The press mud, at many places, is being used as a fuel. The possibilities of using a mixture of filter cake and bagasse in different proportions have been studied to use the mixture as a fuel in the boilers for the generation of steam (Elkader and Yassin, 1989). It can be burnt directly in the form of briquettes. On burning, it emits toxic gases $\mathrm{SO}_{2}$ and $\mathrm{SO}_{3}$ which pollute the environment. Briquettes of press mud, when used in boiler as a fuel, form clinkers (Batish, 1998).

The present methods for disposal of press mud are not economically suitable and pollute the environment. As it contains appreciable proportion of biodegradable organic matter, it has very good potential for the production of biogas. In addition, the digested slurry can be used as a good quality fertilizer. Although few biogas plants, based on press mud, are in operation, their performance is not satisfactory due to the presence of wax and problem of fast acidification. Only few studies have been reported on the anaerobic biomethanation of press mud (Nunet and Silva, 1989 and Sanchez et. al., 1996). Attempts have also been made to produce biogas (methane) from filter cake by mixing it with bagasse (Dasgupta and Nemerow, 1988), and agricultural and other wastes (Mudamwav et. al. 1999). Optimization of biogas generation from press mud in batch reactor has been studied by Rouf et. al., 2010. Design and economics of floting cover biogas plants for digester volume (Eusuf and Ashraf, 1982), for cost optimization (Eusuf and Ashraf, 1982), for minimum 


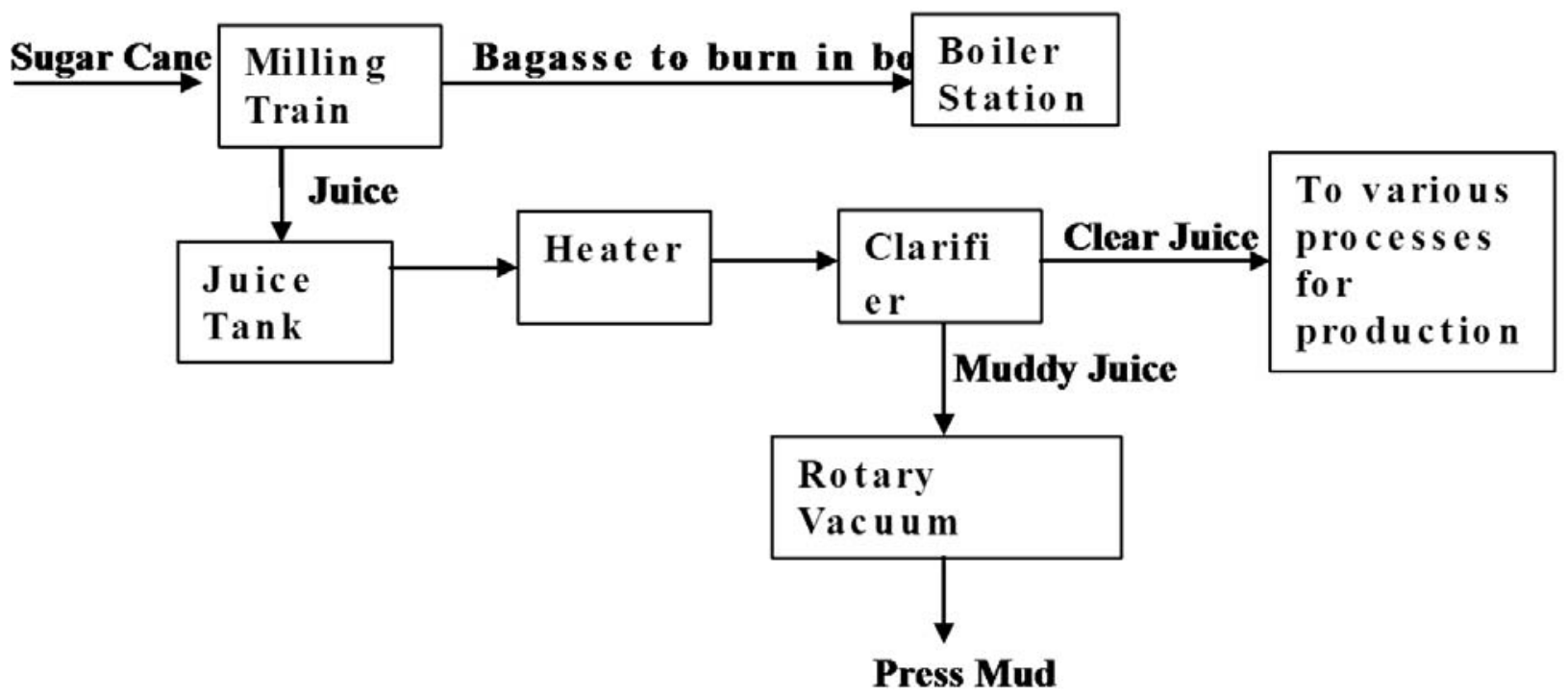

Fig. 1. A schematic diagram of formation of press mud waste in sugar mill (Neha et. al. 2011)

payback period (Eusuf and Ashraf, 1982) And for costruction and performance (Eusuf et. al., 1986) has been studied. An approach to the economic evaluation of family size biogas plants has also been studied (Eusuf, 1984).

This paper is structured as follows: Firstly, physico-chemical characterization of several press mud samples is given as press mud is a potential source of biogas production. The second part of the paper focuses on laboratory batch experiment for biogas production and a field study of a biogas plant in semi continuous process for economic assessment is then presented. The methodologies used for the economic assessment, are a discounting method and a dynamic Net Present Value (NPV) method.

\section{Materials and methods}

Collection of press mud samples

The press mud samples were collected from seven different sugar mills in Punjab, India and one sugar mill in Natore, Bangladesh. The samples were stored in a cold room, maintained at $4^{\circ} \mathrm{C}$, before analysis and other experiments in the laboratory.

\section{Characterization of sample}

Carbon and nitrogen contents in the press mud were determined with the help of a C-H-N elemental analyzer. Its moisture and ash contents were estimated by gravimetric methods by drying at $105^{\circ} \mathrm{C}$ and by complete combustion at $800^{\circ} \mathrm{C}$ respectively. Volatile matter and calorific value were determined according to IS: 10158-1982 and IS: 1350 (Part 4)197 by bomb calorimeter respectively. For estimation of fiber content, about 20 gm of press mud was weighed accurately and washed over a tared 200 mesh sieve until the water run clear. Excess water is drained off and the sieve along with its contents was dried in an oven at $105^{\circ} \mathrm{C}$ to a constant weight. Fiber content is calculated from the increase in weight of the tared sieve (Mathur, 1997).

Chemical oxygen demand (COD) of the sample was estimated by oxidizing the substrate with potassium dichromate and then titrating by ferrous ammonium sulphate (APHA, 1992). Silica was determined according to the procedure of Vogel, 1969. The wax content was measured by extracting with benzene in a Soxhlet apparatus and then distilling it to remove the benzene and quantitatively recovering the wax. Sugar content in the press mud sample was determined by measuring the optical rotation of the filtrate solution of 25 gm press mud in $200 \mathrm{~mL}$ water using polarimeter. Sodium, potassium and calcium contents were determined by flame photometer according to IS: 10614-1983. Phosphate content was determined according to IS: 6361-1971. The protein content was estimated from the nitrogen content by multiplying it with 6.25 . For the determination of sulphate in the press mud, the sample was heated with hydrochloric acid. The clear solution was used for the precipitation of barium sulphate by the addition of dilute barium chloride solution. 
Sulphate content was estimated by gravimetric method. The sample was fused with sodium carbonate to oxidise the sulphite, present in the sample, to sulphate then fused sample was dissolved in acidic water and the clear solution was used to precipitate the original sulphate plus sulphite (converted into sulphate) in the form of barium sulphate. Deducting the earlier value of sulphate from this new value of sulphate gave the sulphite content (Vogel, 1969).

\section{Anaerobic Biomethanation in laboratory}

The collected press mud sample from Natore, Bangladesh was diluted to about $10 \%$ in a 2 liter capacity wide mouth glass bottle. Volume of the substrate in the bottle was one liter. It was inoculated with the sludge collected from an anaerobic plant based on cow dung and pre-acclimatized with press mud for 10 days. The bottle was kept in a room, maintained at about $30^{\circ} \mathrm{C}$. The total gas production was measured by using water displacement method at an interval of 24 hours. Contents of the bottle were mixed manually, after every gas measurement. Daily gas production was recorded.

\section{Anaerobic Biomethanation in the field}

One biogas plant of daily gas production capacity of $150 \mathrm{cft}$ $\left(4.25 \mathrm{~m}^{3}\right)$ has been set up for pilot plant studies. In order to generate biogas from the press mud and maintain its continuity, 40 tons of press mud was collected from the Natore Sugar Mill and stored for 6 months.

Initially, the plant was charged with 3 tons of cow dung as seeding materials with double amount of water. After 10 days of incubation, charging with press mud was started with $50 \mathrm{~kg}$ cow dung and $50 \mathrm{~kg}$ press mud mixed with $200 \mathrm{~kg}$ of water for acclimatization of bacteria in press mud. The charging with this proportion of cow dung and press mud was continued for 20 days. After 30 days the plant was fully operated by $100 \mathrm{~kg}$ press mud with $200 \mathrm{~kg}$ of water per day. The daily gas production was recorded with gas flow meter and ambient temperature was recorded. The $\mathrm{pH}$ of the press mud was 6.1 but after digestion the $\mathrm{pH}$ of the digested slurry was 7-7.2 with a nominal retention time of 40 days and at ambient temperature of $25-35^{\circ} \mathrm{C}$.

\section{Analysis of produced biogas}

Gas analysis has been done by Gas Chromatograph, using porapak Q column and thermal conductivity detector for methane and carbon dioxide in biogas samples. Analytical grade hydrogen was used as a carrier gas at a flow rate of 35 $\mathrm{ml}$ per minute. Oven, detector and injector temperature were maintained at 40,70 and $100^{\circ} \mathrm{C}$ respectively. The electric current was maintained at $120 \mathrm{~mA}$. Calibration of gas chromatograph was done with the standard gas mixture supplied by EDT Research, London. Oxygen was determined with the help of Orsat apparatus by using alkaline pyrogallol solutions as the absorbents (Vogel, 1969).

\section{Results and discussion}

Laboratory Study

Characteristics of different samples are given in the Table I. The moisture content in the samples varied from 74.2 to $78.0 \%$ with an average of $76.7 \%$ which is with time in the range of $60-85 \%$ by Desdin et. al. 1995 . However, the moisture contents of press mud from some South African sugar mills in the range of 60-69.6\% and from an American sugar mill 57.6\% (Dasgupta and Nemerow, 1988) have been

Table I. Characteristics of press mud samples collected from Panjab, India and Natore, Bangladesh

\begin{tabular}{llcc}
\hline Sl. No. Parameter & \multicolumn{2}{c}{ Samples } \\
\cline { 3 - 4 } & & $\begin{array}{c}\text { Panjab, } \\
\text { India }\end{array}$ & $\begin{array}{c}\text { Natore, } \\
\text { Bangladesh }\end{array}$ \\
\hline 1 & Moisture (\%) & 76.7 & 77.8 \\
2 & Solids (\%) & 23.8 & 22.2 \\
3 & Volatile Matter (\%) & 76.6 & 77.1 \\
4 & Ash (\%) & 22.4 & 22.1 \\
5 & Wet Bulk Density (gm/cc) & 0.76 & 0.77 \\
6 & Fibre (\%) & 23.6 & 23.5 \\
7 & Sugars (\%) & 6.4 & 5.7 \\
8 & Wax (\%) & 7.2 & 8.4 \\
9 & Protein (\%) & 15.8 & 15.1 \\
10 & Calorific Value (kcal/kg) & 3861 & 3746 \\
11 & C/N Ratio & 14.0 & 14.2 \\
12 & pH of 10\% solids & 7.5 & 7.1 \\
13 & COD of 10\% solids (g/L) & 86.9 & 84.2 \\
\hline
\end{tabular}

reported. In fact, the moisture content of press mud depends on the efficiency of dewatering (filteration) system used in the sugar mills and the environmental condition.

The sugar, fiber, crude wax, crude protein and total ash were found in the range of 5.7-7.2, 22.5-24.9, 5.3-10.3, 15.1-17.0 and $20.0-24.1 \%$ respectively. The reported values for these components are $2-5,10-20,5-10,5-14$ and $20-30 \%$ respec- 
tively (Rao, 1997). Whereas Dasgupta and Nemerrow, 1988 have reported sugar 10 , fiber 15 , crude wax 9.5 , protein 12.1 and ash $14.5 \%$.

The $\mathrm{C} / \mathrm{N}$ ratio of the press mud sample varied from 13.6 to 14.7 and the average $\mathrm{C} / \mathrm{N}$ ratio was found to be 14.0. The value of $\mathrm{C} / \mathrm{N}$ ratio reported by other investigators is also around 14 (Dasgupta and Nemerow 1988. In fact, the chemical composition of press mud depends on the cane variety, soil conditions, nutrients applied in the field, process of clarification adopted and other environmental factors. The organic content of the press mud, in the form of volatile matter, varied from 74.9 to $78.7 \%$, within the range of reported values of $70-80 \%$ (Rao, 1997). The COD of $10 \%$ press mud slurry was between $79.3 \mathrm{~g} / \mathrm{L}$ to $100.3 \mathrm{~g} / \mathrm{L}$, which is quite close to the one distillery effluent.

Detailed analysis of the press mud ash indicates a silica content of 2.5 to $5.1 \%, \mathrm{CaO}$ of $1.9-2.9 \%, \mathrm{~K}_{2} \mathrm{O}$ of $0.7-1.3 \%$, $\mathrm{Na}_{2} \mathrm{O}$ of $0.2-0.5 \%$ and phosphates of $2.4-3.8 \%$ (Table II). The sulphate and sulphite percentages in the ash were determined to be $0.2-0.8 \%$ and $0.6-2.0 \%$ respectively as indicated in Table II. Typical composition of organic components and micronutrients present in the press mud has been analyzed as shown in Table III. The values were found to be 11.6, 10.2, 9.0 and 15.3 for cellulose, hemicellulose, lignin and protein respectively. These values are quite close to

Table II. Analysis of ash of press mud samples collected from Panjab, India and Natore, Bangladesh

\begin{tabular}{llcc}
\hline Sl. No. & Components (\%) & \multicolumn{2}{c}{ Samples } \\
\cline { 3 - 4 } & & $\begin{array}{c}\text { Panjab, } \\
\text { India }\end{array}$ & $\begin{array}{c}\text { Natore, } \\
\text { Bangladesh }\end{array}$ \\
\hline 1 & Sulphite & 0.94 & 0.66 \\
2 & Sulphate & 0.40 & 0.28 \\
3 & $\mathrm{Na}_{2} \mathrm{O}$ & 0.43 & 0.58 \\
4 & $\mathrm{~K}_{2} \mathrm{O}$ & 0.87 & 0.97 \\
5 & $\mathrm{CaO}$ & 2.47 & 2.95 \\
6 & $\mathrm{SiO}_{2}$ & 4.09 & 4.24 \\
7 & $\mathrm{PO}_{4}$ & 3.13 & 3.43 \\
\hline
\end{tabular}

these reported by Dasgupta and Newmerow, 1988 except the lignin content, which was reported to be $1 \%$.

As the press mud contains appreciable amount of biodegradable matter, represented by volatile organic matter, it is a very good source for biogas production by anaerobic bio-
Table III. Composition of organic components and Micro nutrients present of a typical press mud sample from Natore sugar mill, Bangladesh

\begin{tabular}{cc}
\hline Component & Percentages (on dry basis) \\
\hline Cellulose & 11.6 \\
Hemicellulose & 10.2 \\
Lignin & 9.0 \\
Protein & 15.3 \\
$\mathrm{Na}$ & 0.21 \\
$\mathrm{~K}$ & 0.41 \\
$\mathrm{Ca}$ & 2.09 \\
$\mathrm{Mg}$ & 0.35 \\
$\mathrm{Fe}$ & 0.31 \\
$\mathrm{Zn}$ & 0.01 \\
$\mathrm{Co}$ & trace \\
$\mathrm{Ni}$ & 0.01 \\
$\mathrm{Cr}$ & 0.03 \\
$\mathrm{Mn}$ & 0.02 \\
\hline
\end{tabular}

methanation. Various micro nutrients are also required for biomethanation. The press mud was also analyzed for the micro nutrient.

From the characterization of press mud samples, it was found that although some variation in composition was observed in the press mud sample, but variation is not significant except in case of wax content.

\section{Daily Gas Production}

Fig. 2 represents the volumes of daily gas accumulation and it shows a belt shape trend. It was observed that gas generation started at the very next day of charging the digesters with the slurry. The rate of gas generation gradually increased with increasing the digestion period. The graph also indicates that during the digestion period, most of the daily gas production range was between 200 and $600 \mathrm{~mL}$. In this reactor, the peak gas production of $1100 \mathrm{~mL}$ was observed on the 20th day. It was observed that gas production rate declined after 26th days.

\section{Cumulative Gas Production}

The cumulative gas production from the test reactor operating in the laboratory shows that the lag phase prevailed up to 5 to 6 days of digestion period (Fig. 3). This was due to microbe limiting at the initial stage of fermentation. The 


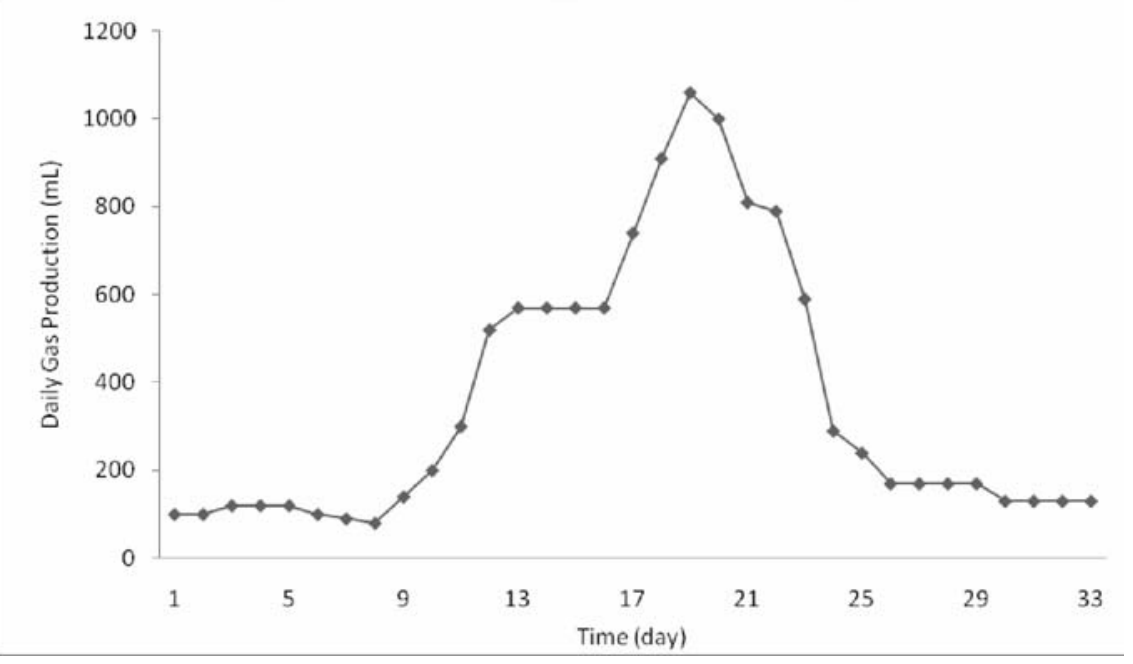

Fig. 2. Daily gas production in the laboratory experiment

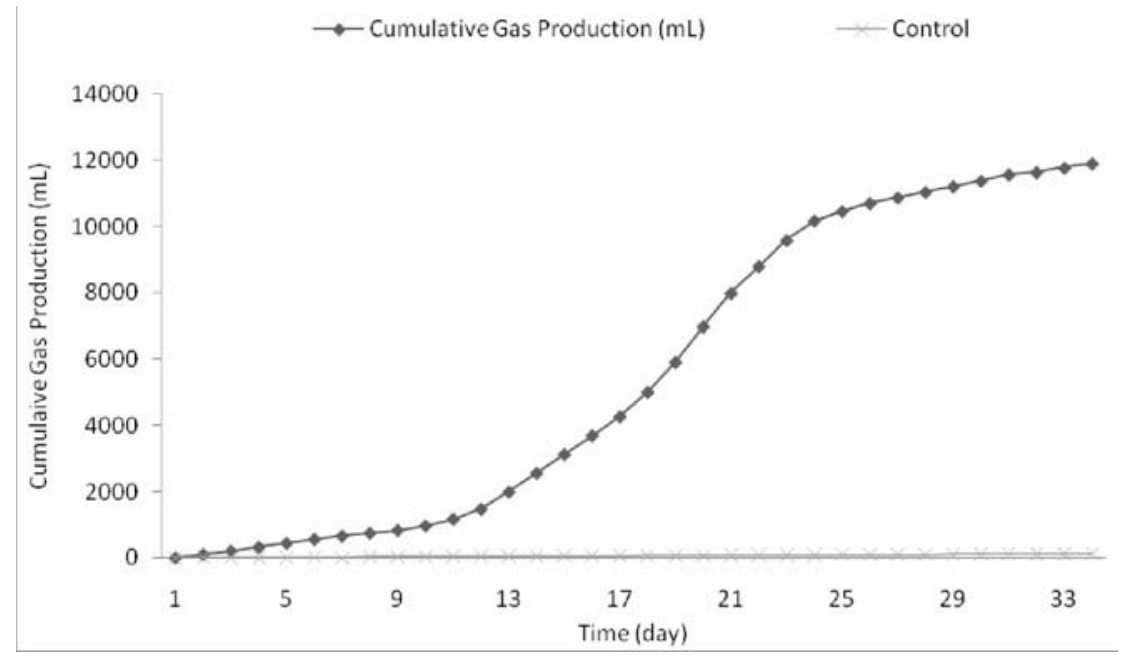

Fig. 3. Cumulative gas production in laboratory experiment

longer the lag phase, the longer the time delay of peak gas generation. After the lag period, the cumulative volume of gas increased sharply and continued up to 30 to 33 days of fermentation period. After which the rate of gas generation decreased and this declination continues until the gas generation almost ceased.

Fig. 4 represents the variation of cumulative gas production over different time periods. The figure shows that the highest gas generated after 15 days of digestion period. In the first and last 5 day digestion period, generation of gas was low.
Field Study

The yield of biogas from press mud for 1st, 2nd, 3rd, 4th, 5th month respectively is shown in Fig. 5. The gas yield has been found to increased from 1 st 30 days to 4 th 30 days, then gas yield goes almost constant. There was a little fluctuation in gas production in every 30 days. Fig. 6 represents the variation of cumulative gas production at different time for 6 months. The figure shows that the cumulative gas production increases up to 4 th 30 days then its goes to almost constant production of cumulative gas in each 30 days. The $\mathrm{CH}_{4}$ content of produced biogas was found to be about $65 \%$. 


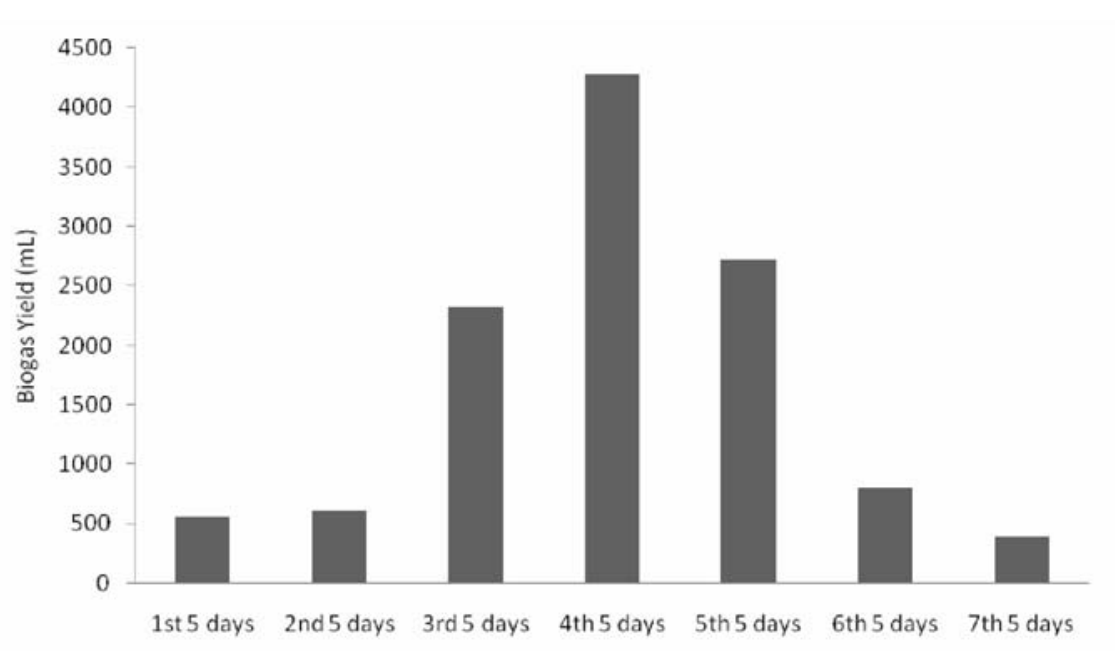

Fig. 4. Cumulative gas production over different 5-day periods extending up to 35 days in laboratory experiment

\section{Economic analysis}

For economic analysis capital investment estimates, investment related costs are calculated based on several general assumptions. The main assumptions concerning investmentrelated costs, raw materials prices, transportation costs, revenues, process costs (labour and maintenance etc.) are summarized in Table V. The discount rate is set as $12 \%$. The revenue is primarily derived from the sale of biogas as fuel and slurry as fertilizer. The life time of the plant assumed to be 20 years, the projects Net Present Value (NPV) is then deter mined (Balussou et. al., 2012) and the calculation of dynamic Payback Period $t_{\text {eq }}$ (defined as the amount of time required to recover the cost of an investment and associated interest repayments) is derived from the cash flows.

\section{Capital Investment Estimates}

The total capital investments of a biogas plant for a $150 \mathrm{ft}^{3}$ or $4.25 \mathrm{~m}^{3}$ production capacities per day is $46000.00 \mathrm{Tk}$ (Table IV). This includes plant construction costs and cost of 3 tons of cow dung to start up the plant.

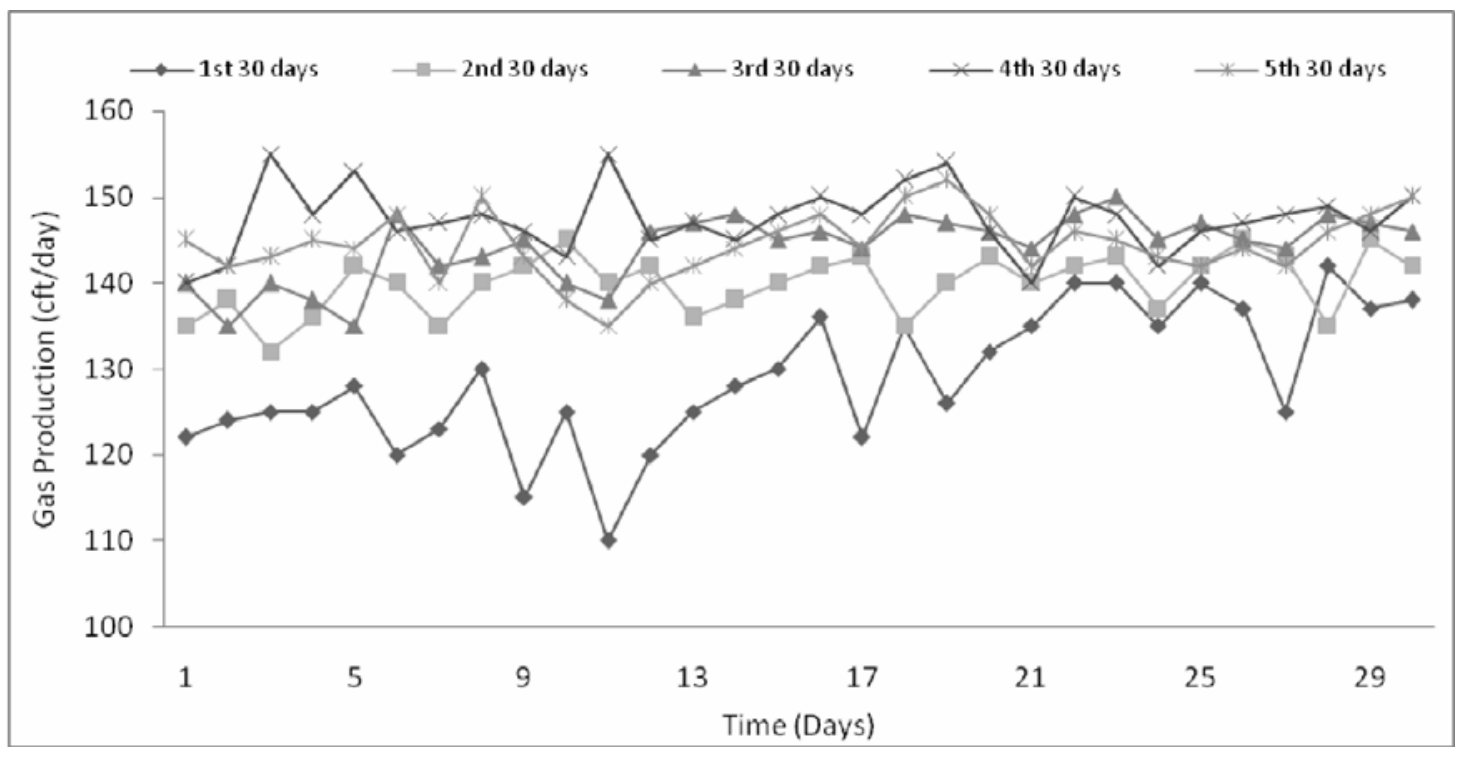

Fig. 5. Daily gas production during consecutive 30-day periods extending up to 150 days in the field biogas plant 


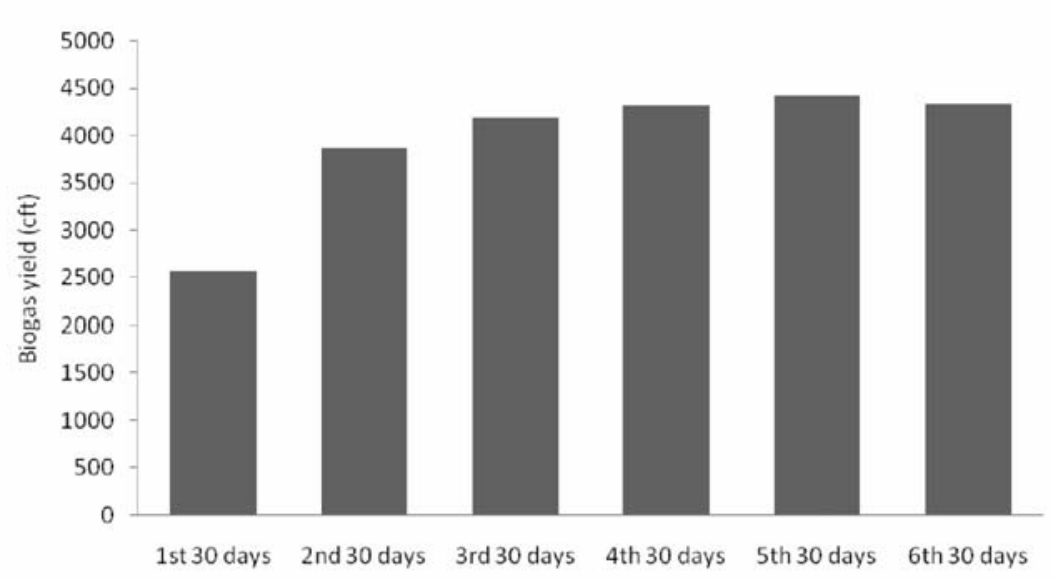

Fig. 6. Cumulative gas production over different 30-day periods extending up to 150 days in field biogas plant

\section{Operating and Investment-Related Costs}

Operating and investment-related costs consists of depreciation and interest. Depreciation costs are evaluated at 1200.00 tk ( $3 \%$ of plant construction cost). The cost of raw materials (press mud) with carrying charge and process costs (labour and maintenance etc.) are 36500.00 and $6000.00 \mathrm{Tk}$ respectively (Table IV). The total annual operating and investmentrelated costs are $43700.00 \mathrm{Tk}$.

\section{Revenues}

The revenue of plant is derived from sale of biogas and biofertilizer. It is assumed that $\mathrm{CH}_{4}$ content in biogas is $65 \%$ and then compare with the local price of natural gas, 30.00 $\mathrm{tk} / \mathrm{m}^{3}$. The price of biofertilizer is $2.00 \mathrm{Tk} / \mathrm{kg}$ is estimated with $40 \%$ moisture content (sun dried). The total annual revenues are consequently $52150.00 \mathrm{Tk}$.

\section{Profitability Analysis}

The operating profit for the plant stands for the difference between the annual total revenues and total investment-related costs. Finally the dynamic payback period obtained is 9.35 years, internal rate of return is $18 \%$ and NPV is 15282.86 tk as shown in Fig. 7 of cumulative cash flow rate with time of 20 years.

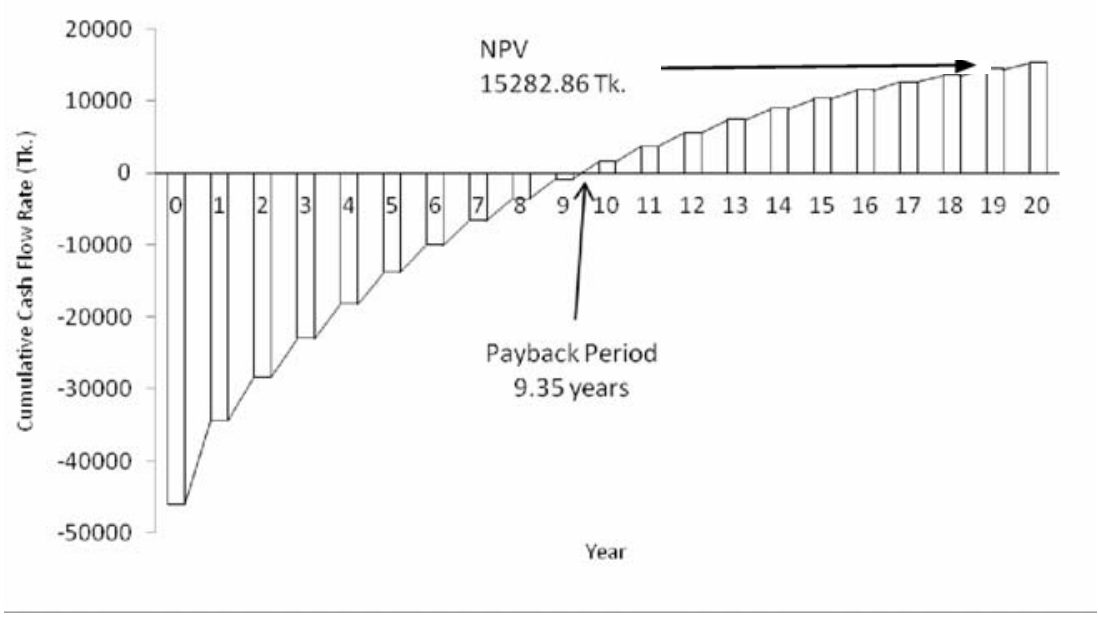

Fig. 7. Cumulative cash flow rate with time (year) 
Table IV. Capital Investment, Operating Cost and Revenues for the field biogas plant

\begin{tabular}{llr}
\hline Cash Flow & \multicolumn{1}{c}{ Purpose } & Amount (Taka) \\
\hline Capital Investment & Plant construction cost & 40000.00 \\
& Cost of 3 tons cow dung with carrying charge & 6000.00 \\
Yearly Operating Cost & Press mud with carrying charge $(100 \mathrm{~kg} \times 365=36.5$ ton@ 1000 tk./ton) & 36500.00 \\
& Labour and maintenance & 6000.00 \\
& Depreciation cost $(3 \%$ of plant construction) & 1200.00 \\
Yearly Income & From gas sale $\left(1551.25 \mathrm{~m}^{3} \times 65 \%\right.$ as CH $\left.@ 30 \mathrm{tk} . / \mathrm{m}^{3}\right)$ & 30250.00 \\
& Cost of total fertilizer $(100 \mathrm{~kg} \times 0.75 \times 0.40) @ 2 \mathrm{tk} . / \mathrm{kg}$ & 21900.00 \\
\hline
\end{tabular}

\section{Conclusion}

The present methods for disposal of press mud from sugar industry are not environmentally sound. Its disposal is a problem and creates environmental nuisance. But generation of biogas from the substrate will reduce environmental problem. It has been found from the characterization of press mud that, both in India and Bangladesh, the organic matter content is high, so they are suitable for biogas production. The sugar industry will be financially benefited by installing biogas generators, as the economic analysis reveals that the production of biogas and biofertilizer from press mud is economically feasible. Furthermore, there is triple benefit associated with the waste bio-methanation as we get clean fuel biogas, enriched manure biofertilizer and also hygienic environment.

\section{References}

APHA, AWWA and WEF (1992), Standard Methods for the Examination of Water \& Wastewater (18th ed.), American Public Health Assn., Washington DC.

Balussou D, Kleybocker A, McKenna R, Most D and Fichtner W (2012), An economic analysis of three operational co-digestion biogas plants in Germany, Waste Biomass Valor. 3: 23-41.

Batish JP (1998), Clinker formation of press mud briquettes when used as a boiler fuel, Private Communication, Rakhra Fuel Products, Rakhra, Punjab.

Dasgupta A and Nemerow NL (1988), Anaerobic digestion of lingo cellulosic residue from sugarcane processing, Energy Biomass Waste, 11: 613.

Desdin L, Gonzalez D and Labrada A (1995), Moisture measurement in the filter press mud by gamma transmission method, J. Radiational. Nucl. Chem. 201(4): 321.

Elkader AA and Yassin AA (1989), Filter mud as fuel for steam generation in Egypt, Proc. of the XX Congress of ISSCT, p. 326.

Eusuf M and Arshad Ali M (1982), Design and economics of floating cover biogas plants. Part-I: Optimization of digester volume for minimum capital cost, BangladeshJ. Sci. Ind. Res. 17: 136
Eusuf M and Arshad Ali M (1982), Design and economics of floating cover biogas plants. Part-II: Cost optimization, Bangladesh J. Sci. Ind. Res. 17: 140

Eusuf M and Arshad Ali M (1982), Design and economics of floating cover biogas plants. Part-III: Minimum payback period, Bangladesh J. Sci. Ind. Res. 18: 144

Eusuf M, Bhuiya TA and Haque MS (1986), Design and economics of floating cover biogas plants. Part-IV: Construction and performance of a cheaper design, Bangladesh J. Sci. Ind. Res. 21: 167-175.

Eusuf M (1984), An approach to the economic evaluation of family size biogas plants, Bangladesh J. Sci. Ind. Res. 19: $220-238$.

Mathur RBL (1997), Handbook of Cane Sugar Technology, IBH Publishing Co., New Delhi, p. 248.

Mudamwar D, Patel V and Patel A (1990), Effect of agricultural and other wastes on anaerobic digestion of water hyacinth-cattle dung, J. Ferment. Bioeng. 70(5): 343.

Neha G, Sumit T and Chandrajit B (2011), Characterization of press mud: A sugar industry waste, Fuel, 90 (1): 389-394.

Nunet AG and Silva L (1989), A study on the production of biogas from filter press mud, Proc. of the XVIII Congress of ISSCT, p. 1499.

Rao PJM (1997), Industrial Utilization of Sugar Cane and Its Co-products, ISPCK Publishers, Delhi, p. 472.

Rouf MA Bajpai PK and Jotshi CK (2010), Optimization of Biogas Generation from Press Mud in Batch Reactor. Bangladesh J. Sci. Ind. Res. 45 (4): 371-376

Sanchez E, Borja R and Lopet M (1996), Determination of the kinetic constants of anaerobic digestion of sugar mill mud waste, Bioresource Technol. 56(2\&3): 245.

Vogel IA (1969), A Text Book of Quantitative Inorganic Analysis, 3rd ed., Longman Group Ltd., London.

Received: 21 June 2012; Revised: 25 March 2013; Accepted: 31 March 2013. 